\title{
ZOOGEOGRAPHICAL ANALYSIS OF THE EGYPTIAN SCORPION FAUNA
}

\author{
Mostafa Saleh $^{1}$, Mahmoud Younes ${ }^{1}$, Ahmed Badry $^{1}$ and Moustafa Sarhan ${ }^{2}$ \\ Departments of Zoology, Faculty of Science, Al Azhar University, Nasr City, Cairo ${ }^{1}$ and Assuit ${ }^{2}$, Egypt
}

\begin{abstract}
The geographical distribution and diversity of the scorpion fauna of Egypt was examined based on a large collection covering most of the country and in view of recent revisionary systematics. Six ecologically distinct zoogeographical regions are targeted in a collection scheme. The ecological and historical biogeography of the present-day distribution of the scorpion fauna of Egypt is discussed.
\end{abstract}

Key Word. Zoogeography, Scorpion Fauna, Buthidae, Euscorpiidae, Hemiscorpiidae, Scorpionidae, Egypt

\section{INTRODUCTION}

Scorpions comprise a highly successful and diverse order of Arachnida. Except Antarctica, scorpions distributed over all continents (Lamoral, 1980; Sissom, 1990). It inhabits a great range of the world of tropical and temperate regions including; forests, savannas and deserts (Anderson, 1983).

The scorpion fauna of Egypt is represented by four families; Buthidae, Euscorpiidae, Hemiscorpiidae and Scorpionidae. During the past century, considerable information about scorpion fauna of Egypt and the region, have been complied, reviewed and synthesized by several authors (e.g. Simon, 1910; Gough and Stanley, 1927; Pallary, 1937; Vachon, 1952; 1966; Levy and Amitai, 1980; Vachon and Kinzelbach, 1987). Numerous publications have contributed significantly to our growing knowledge of the composition, ecology and biogeography of scorpions of Egypt at large (Kinzelbach, 1985; Moustafa, 1988; ELHennawy, 1992; Lourenço et al., 2009a, b; Teruel et al., 2013). These authors refer to a total of 35 scorpion species from Egypt. All of these species were listed in a compiled lists ElHennawy $(1992,2014)$. Some of these species records are unclear and dubious (Kovarik, 2007; Kaltsas et al., 2008) and should be further reviewed and verified. Moreover, the taxonomy and diversity of the scorpion fauna of Egypt was examined based on a large collection from most parts of the country and in view of recent revisionary systematics. The validity of listed records was assessed in light of new taxonomic findings and geographic distribution data and present a new list provided with an identification key to the scorpion fauna of Egypt consisting of 31 species and four dubious species (Badry et al., 2017). In addition, the precise patterns of geographical and ecological distribution of most scorpion species in Egypt are yet to be determined.

Egypt occupies one of the most arid areas on the globe. It's an important part of North Africa, which are home to a unique fauna and flora that has been shaped by the combination of several factors including the harsh climatic conditions of the Sahara the episodic appearance of humid cycles, and by the complex geological evolution of this area. The aim of this paper is to explain current geographical distribution of different scorpion species from Egypt.

\section{MATERIALS AND METHODS}

\section{Study area}

The study covers the entire country of Egypt (Figure, 1 and Table, 1), which is traditionally divided into a number of ecogeographical regions, each encompassing a number of basic habitat types (Kassas, 1993; 
Saleh, 1993). These eco-geographical regions can be summarized as following;

The Mediterranean Coastal Desert: This narrow coastal strip of 30 to $50 \mathrm{kms}$ extends along the Egyptian coast of the Mediterranean. It receives more rainfall than any other area in Egypt. With the exception of the extreme eastern part, which is considered semi-arid, the rest of the coastal belt is climatically arid. The hyper-arid barren desert to the south forms a major ecological barrier separating this belt from the patchy inland habitats of the Western Desert to the south (Saleh, 1993). The Mediterranean coastal belt is interrupted by the Nile Delta which divides it into the Western Mediterranean Coastal Desert (WMCD) to the west, and the Eastern or Sinai Mediterranean Coastal Desert (SMCD) to the east. These two sectors, differ geomorphologically, climatologically and ecologically from each other (Saleh, 1997) and are, therefore, treated in this study as two separate eco-geographical regions.

The Western Inland Desert (WID): South of the Mediterranean coastal desert, the Western Desert is almost rainless. The flat topography of that desert allows very little, if any, significant collection of the rare local rain to support even the most rudimentary life. In the topographic depressions scattered throughout that desert, however, ground water may reach the surface creating oases and other isolated patches of life in this otherwise barren desert. These patchy habitats are surrounded by vast tracks of barren desert which represent a formidable ecological barrier to animals, particularly those with limited dispersal abilities. Patchy inland habitats of the Western Desert include the inhabited oasis groups of Siwa, Bahariya, Farafra, Dakhla, and Kharga, as well as numerous uninhabited oases, acacia groves and vegetation patches scattered throughout that desert, the largest of which is the Qattara Depression and its satellite oases. Within most of the large oasis depression life is distributed in smaller secondary patches where water is available forming individual oases that are often separated from each other by barren desert.

The Nile Valley and Delta (NVD): The River Nile, which cuts its course across the entire length of the country, carries an abundance of water from the remote African highlands into this extremely arid part of the Sahara, creating in its narrow valley and delta the largest riverine oasis in the world. The river flows mostly close to the north-south aligned hills of sandstone and limestone of the Eastern Desert. South of the large and intensively cultivated Nile Delta, the present-day flood plain of the Nile becomes very narrow, particularly on the eastern side, where the river washes the feet of the sedimentary hills of the Eastern Desert in some places. Adjoining the river's western flood plain just south of the latitude of Cairo is the Faiyum Depression. The depression receives its water from the Nile via the Bahr Yusuf canal, which is possibly a natural branch of the Nile. South of Aswan, the river cuts a deep, gorge-like course through the Nubian Plateau. This fast running sector of the river is interrupted by a series of rapids forming what is known as the river Cataracts. From the First Cataract just south of Aswan, the river virtually lacks any flood plain, except for few patches scattered along the river course. Following the damming of the river near Aswan, this sector of the river has been inundated. The resulting Lake Nasser forms one of the major topographic features of the entire river basin.

The Eastern Inland Desert (EID): Unlike the Western Desert, the Eastern Desert exhibits a very diverse and complex topography. A backbone of igneous mountains running along the longitudinal axis of this desert, but closer to the Red Sea coast is the predominant topographic feature. This mountain chain is skirted to the north and west by sedimentary plateaus of limestone and sandstone. Both the igneous mountains and the sedimentary plateaus are dissected by networks of drainage 
channels, which collect water from larger watersheds into the much smaller areas of the wadis or their deltas to eventually discharge into the Red Sea or the Nile River. Wadi channels and deltas thus receive runoff water many times higher than the average local precipitation, which ranges from 25 to $50 \mathrm{~mm}$ annually. The drainage networks also serve as corridors for movement of fauna across this otherwise inhospitable desert. The dramatically different riverine habitat of the Nile Valley and Delta forms a major ecological barrier preventing Eastern Desert fauna from venturing west. To the northeast the Isthmus of Suez, with its wetland presents another ecological barrier between the Eastern Desert and Sinai (Basuony and Saleh, 2005).

The Sinai Peninsula: The Sinai Peninsula is a triangular plateau with its head in the south at Ras Mohammad and its base along the Mediterranean Sea. The peninsula is geologically and geomorphologically an extension of the Eastern Desert, regardless of the Gulf of Suez that separates the two regions. The core of the peninsula; situated near its southern end; consists of an intricate complex of high and very rugged igneous and metamorphic mountains. These mountains are dissected by a large number of wadis flowing either to the Gulf of Aqaba or the plain of Sahel El Qaa and the Gulf of Suez. Most of these wadis are relatively rich in plant and animal life. The Mediterranean littoral desert of Sinai called Sinai Mediterranean Coastal Desert (SMCD) consists of wide, sand-covered plains gradually sloping northward. Eolian sand dunes with elevations of 80 to $100 \mathrm{~m}$ are common throughout the region. Wadi El Arish, a very large northward-flowing wadi, with numerous tributaries draining extensive areas of the Central Sinai highlands is one of the main geomorphologic features of the region. South of the Mediterranean coastal belt of Sinai, a number of distinct hill groups, which include Gabal El-Maghara, Gabal El-Halal, Gabal Yelleq and others form the so-called the region of domes (Abu Al-Izz, 1971), located relatively close to the Mediterranean. These hills receive higher precipitation and support an interesting variety of relict fauna and flora. South of this region, the central Sinai plateau begins called Sinai Inland Desert (SID). This region encompasses the rugged sedimentary country of El Tih and Al-Ugma Plateaus, which are located on the northern flanks of the great igneous core. These plateaus form two ridges, which have the form of straight walls with no gaps (Shata, 1959). Numerous wadis drain the central Sinai plateaus into the lower areas to the north and often support rich and diverse flora (Saleh, 1993).

Each of the above eco-geographical regions is surveyed at a number of collection localities that represent its different habitat types.

\section{Material Examined}

The materials examined during this study consist of a total of 962 scorpion specimens currently deposited at Al Azhar University Zoological Collection (AUZC), Department of Zoology, Al Azhar University, Cairo, Egypt. The majority of these specimens were collected during the course of this study. These specimens were collected from 46 collection localities representing six major ecogeographical regions of Egypt (Figure, 1 and Table, 1). Scorpions were collected by actively searching their potential hiding places, mostly under rocks during daytime (Williams, 1968) and at night using ultraviolet light (Stahnke, 1972). Collected specimens were preserved for future morphological and taxonomical studies, as described by Williams (1968).

\section{Morphological examination and species identification}

The specimens were examined by a stereoscopic binocular microscope, and photographed with a digital camera. The collected scorpions were identified to the species level based on keys and morphological descriptions of Vachon (1966), El-Hennawy 
(1987), Lourenço and Simon (2012) and Rossi (2013).

\section{RESULTS}

The compiled list (Table, 2) shows that scorpion species richness varies considerably among different eco-geographical regions in Egypt (Figure, 2). Among the 31 species belong 15 genera of known collection localities in Egypt (Table 2), Inland (48\% of all species) occur in the the Nile Valley and Delta (NDV) and Eastern Desert (EID). Five species includes; Compsobuthus kabateki, Hottentotta minax, Isometrus maculatus, Parabuthus hunteri and Hemiscorpius egyptiensis) are restricted to Nile Valley and Delta, while only four of these species (Buthus intumescens, Hottentotta scaber, Microbuthus flavorufus and Parabuthus leiosoma) are restricted in their distribution to Eastern Inland Desert (EID) ecoregion. Also, twelve species (38\% of the fauna) are recorded from the Western Mediterranean Coastal Desert (WMCD), four of which (Androctonus tenuissimus, Buthus adrianae, Buthus orientalis and Euscorpius sicanus) are restricted to that ecoregion. Sinai Inland Desert (SID), Sinai Mediterranean Coastal Desert (SMCD) and Western Inland Desert (WID) account for 9, 8, and 8 (29, 25.8, $25.8 \%$ ) of the recorded species, respectively. Three of the Sinai Inland Desert species (Buthus israelis, Compsobuthus longipalpis, and Orthochirus scrobiculosus), and one each of the Sinai Mediterranean Coastal Desert (SMCD) and Western Inland Desert (WID) (Egyptobuthus vaissadei and Buthus egyptiensis, respectively) are restricted to their respective ecoregions.

Different species appear to vary considerably in their distribution among the six eco-geographical regions covered in this study (Figure, 3). Of the 31 species with known collection localities, two species (Androctonus amoreuxi and Leiurus quinquestriatus) appear to have high ecological tolerance and have been recorded from all six eco-geographical regions. On the other hand, 18 species appear to be restricted in their distribution to a specific ecoregion, outside of which it has never been recorded. The remaining 13 species have been recorded from 2 to 5 ecoregions.

\section{DISCUSSION}

Saharan fauna characteristically consists of primarily Palearctic fauna, with some Afrotropical elements (Dobson and Wright, 2000) reflecting the geological, biogeographic and ecologic history of the region. The scorpion fauna of Egypt, similarly consists of both Palearctic and Afrotropical elements. Of the 15 Egyptian scorpion genera, 14 have Palearctic affinity and only one genus (Parabuthus) is Afrotropical. The two Afrotropical species Parabuthus hunteri and P. leiosoma have been reported from the Nile Valley and the arid to semi-arid, extreme southeastern region of Egypt which is dominated by Afrotropical fauna (Saleh, 1993).

One of the most distinct characters of the scorpion fauna of Egypt is its highly disjunct distribution. This is obviously a consequence of the patchy distribution of habitats, which is, in turn dictated by the rare availability of water in this mostly hyper-arid region of the Sahara. Fragmented animal populations, in their habitat patches, are often separated from one another by large tracts of barren desert. This waterless, lifeless desert creates a formidable barrier for the dispersion of scorpion, and even larger animal species with greater mobilization abilities. The isolation of scorpion populations into desert habitat islands may have taken place during the Pleistocene's successive episodes of arid climate, but has finally persisted since the onset of the present arid conditions in the Sahara around the middle of the Holocene (Said, 1990; Roberts, 1998; Béatrix, 2001). This vicariance explanation for the present-day distribution of most terrestrial animal groups in Egypt is more plausible, as dispersal is unlikely to be the mechanism because of the nature of the ecological barriers separating different populations (Nelson and Platnick, 1980; Morrone and Crisci, 1995). 


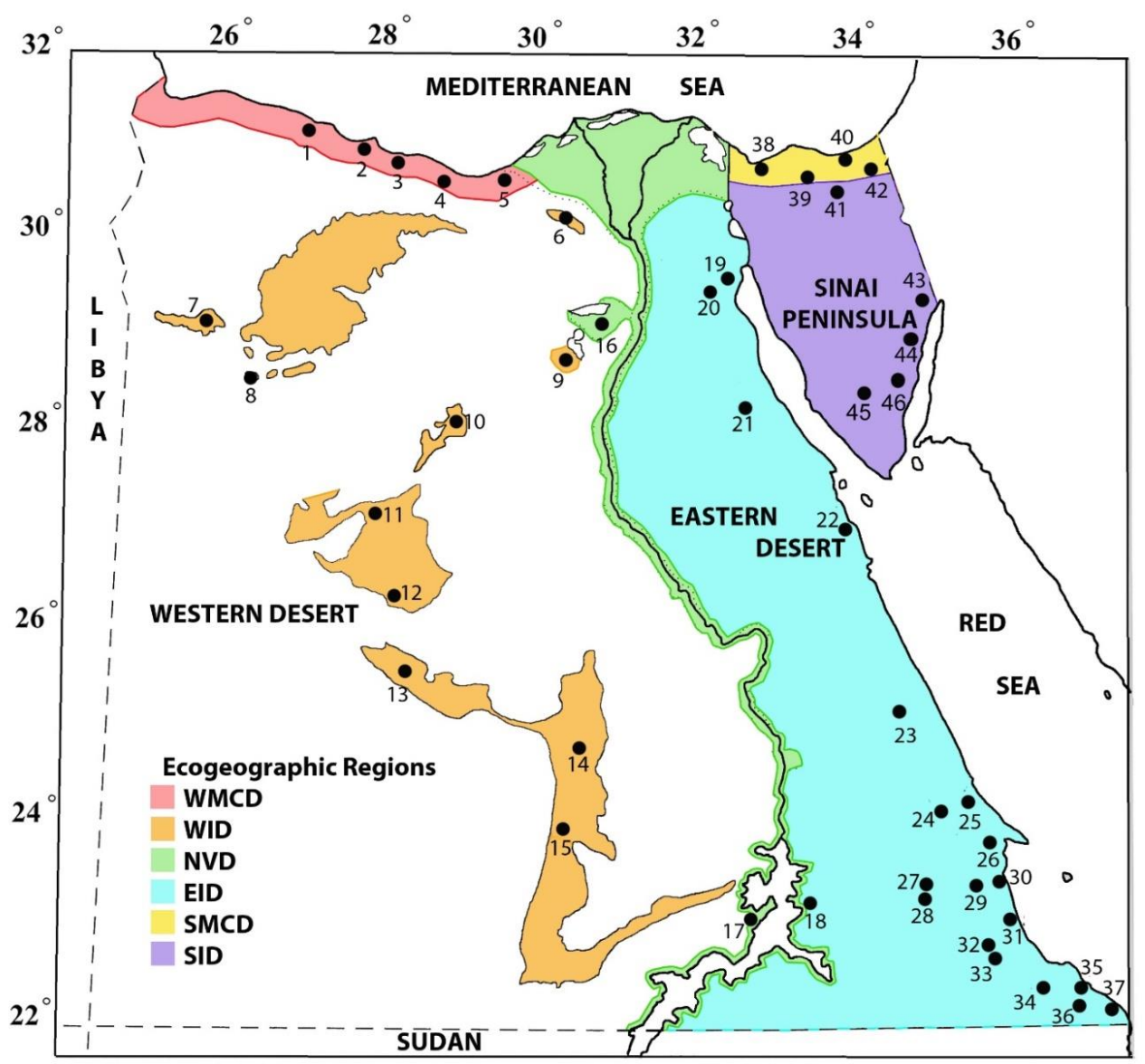

Figure 1. Location map of eco-geographical regions and collection localities covered in this study.

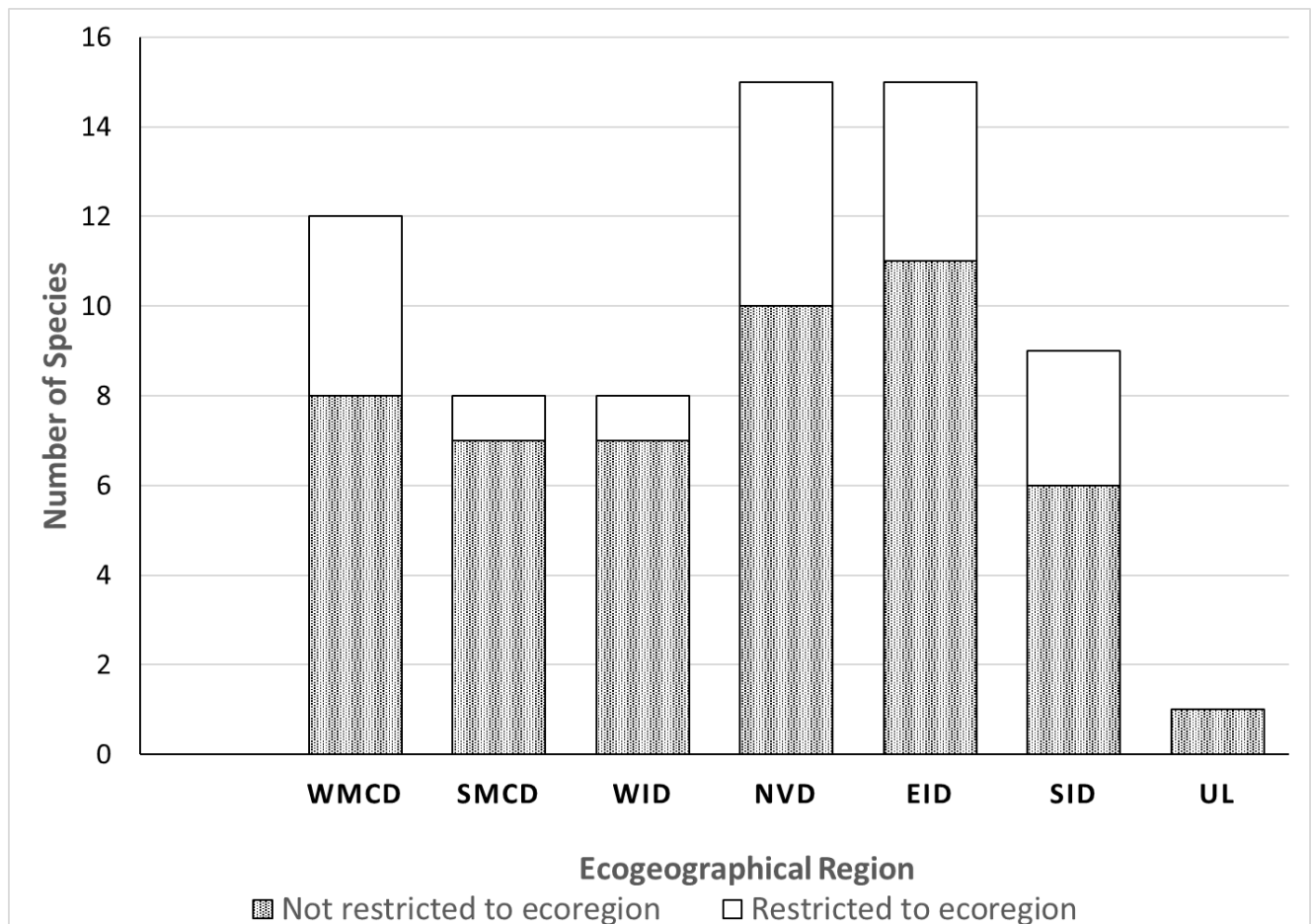

Figure 2. Number of species recorded from different eco-geographical regions of Egypt; WMCD (Western Mediterranean Coastal Desert), SMCD: (Sinai Mediterranean Costal desert), WID (Western Inland Desert), NVD (Nile Valley and Delta), EID (Eastern Inland Desert), SID (Sinai Inland Desert); and UL (unknown localities). 
Table 1. Locations of the investigated sites during the survey. $\mathrm{WMCD}=$ Western Mediterranean Coastal Desert; SMCD = Sinai Mediterranean Coastal Desert; WID = Western Inland Desert; NVD = Nile Valley and Delta; EID = Eastern Inland Desert; SID = Sinai Inland Desert.

\begin{tabular}{|c|c|c|c|c|}
\hline $\mathbf{N}$ & Sites & Eco-geographical regions & Latitudes & Longitudes \\
\hline 1 & Marsa Matruh & \multirow{5}{*}{ WMCD } & 31.1918 & 27.6211 \\
\hline 2 & Sidi Heneish & & 31.0701 & 27.7905 \\
\hline 3 & El-Dabaa & & 30.9626 & 28.4739 \\
\hline 4 & $\begin{array}{l}\begin{array}{l}\text { El-Hammam } \\
\text { protectorate }\end{array} \\
\end{array}$ & & 30.8585 & 29.4026 \\
\hline 5 & Borg El Arab & & 30.6887 & 28.9466 \\
\hline 6 & Wadi El-Natron & \multirow{10}{*}{ WID } & 30.3318 & 30.1212 \\
\hline 7 & Siwa Oasis & & 29.1513 & 25.7934 \\
\hline 8 & Bahrain & & 28.6886 & 26.4508 \\
\hline 9 & Wadi El Rayan & & 29.2147 & 30.4223 \\
\hline 10 & Bahariya Oasis & & 28.2759 & 28.8006 \\
\hline 11 & Farafra Oasis & & 27.0776 & 27.9754 \\
\hline 12 & Abu Mingar & & 26.5060 & 27.6451 \\
\hline 13 & Dakhla Oasis & & 25.4945 & 28.9789 \\
\hline 14 & Kharga Oasis & & 25.7271 & 30.5549 \\
\hline 15 & Baris & & 24.6744 & 30.6079 \\
\hline 16 & Faiyum & \multirow{3}{*}{ NVD } & 29.2799 & 30.5763 \\
\hline 17 & West of Lake Nasser & & 23.2890 & 32.7768 \\
\hline 18 & East of Lake Nasser & & 23.1813 & 32.9883 \\
\hline 19 & Ghobet El Bous & \multirow{19}{*}{ EID } & 29.6180 & 32.0966 \\
\hline 20 & Wadi Ghoeiba & & 29.9080 & 32.3308 \\
\hline 21 & Wadi Al Tarfa & & 28.2618 & 32.1626 \\
\hline 22 & Hurgada & & 27.1416 & 33.6957 \\
\hline 23 & Wadi Nekheil & & 25.1515 & 34.3910 \\
\hline 24 & Wadi Halos & & 24.3936 & 35.0766 \\
\hline 25 & Wadi El Ranga & & 24.3514 & 35.1930 \\
\hline 26 & Wadi Khodaa & & 23.8245 & 35.3134 \\
\hline 27 & Bir Abraq & & 23.4188 & 34.7989 \\
\hline 28 & Abu Saafa & & 23.2984 & 34.7842 \\
\hline 29 & Wadi El Rahaba & & 23.4284 & 35.2395 \\
\hline 30 & Marsa Hemira & & 23.4743 & 35.4813 \\
\hline 31 & Shalateen & & 23.1348 & 35.5909 \\
\hline 32 & Wadi Sha`b & & 22.3155 & 35.9493 \\
\hline 33 & El Garf & & 22.6664 & 35.3502 \\
\hline 34 & Wadi El-De'ib & & 22.2065 & 36.3777 \\
\hline 35 & Abu Ramad & & 22.3936 & 36.4011 \\
\hline 36 & Wadi Aydeib & & 22.2065 & 36.3777 \\
\hline 37 & Halayeb & & 22.1694 & 36.6665 \\
\hline 38 & Bir El-Abd & \multirow{5}{*}{ SMCD } & 31.0142 & 32.7486 \\
\hline 39 & Gabal Yelleq & & 30.3688 & 33.5161 \\
\hline 40 & El Arish & & 31.0729 & 33.8326 \\
\hline 41 & Gabal El-Maghara & & 30.6776 & 33.4845 \\
\hline 42 & El Shikh Zuweid & & 30.8828 & 34.0629 \\
\hline 43 & El Naqab Desert & \multirow{4}{*}{ SID } & 29.5339 & 34.7031 \\
\hline 44 & Wadi El Shafalah & & 29.3246 & 34.5997 \\
\hline 45 & Wadi Arada & & 28.8620 & 34.1604 \\
\hline 46 & Ain Khadra & & 28.8959 & 34.4223 \\
\hline
\end{tabular}


Table 2. Scorpion families and species recorded from different eco-geographical regions of Egypt based on published data and the results of the present survey. WMCD $=$ Western Mediterranean Coastal Desert; SMCD = Sinai Mediterranean Coastal Desert; WID = Western Inland Desert; NVD = Nile Valley and Delta; EID = Eastern Inland Desert; SID = Sinai Inland Desert; UL = Unknown Localities/Dubious record.

\begin{tabular}{|c|c|c|c|c|c|c|c|c|}
\hline \multirow{2}{*}{ Family and species } & \multicolumn{7}{|c|}{ Eco-geographical Region } & \multirow[t]{2}{*}{ Authority* } \\
\hline & WMCD & SMCD & WID & NVD & EID & SID & $\mathbf{U L}$ & \\
\hline \multicolumn{9}{|l|}{ DEFINITIVE SPECIES } \\
\hline \multicolumn{9}{|l|}{ Buthidae } \\
\hline Androctonus amoreuxi & + & + & + & + & + & + & - & $\begin{array}{l}1,2,3,4,5,6,7 \\
8,9\end{array}$ \\
\hline Androctonus australis & + & + & + & + & + & - & - & $\begin{array}{l}1,3,4,5,8,10 \\
11,12,13\end{array}$ \\
\hline Androctonus bicolor & + & + & - & + & + & - & - & $\begin{array}{l}1,2,3,4,5,8, \\
12,13,14,15\end{array}$ \\
\hline Androctonus crussicauda & - & + & - & - & - & + & - & $1,13,14,15$ \\
\hline Androctonus tenuissimus & + & - & - & - & - & - & - & 1,16 \\
\hline Buthacus arenicola & + & - & - & - & + & - & + & 17 \\
\hline Buthacus leptochelys & + & + & + & + & + & - & - & $\begin{array}{l}1,3,5,8,10,13, \\
14,18,19\end{array}$ \\
\hline Buthus adrianae & + & - & - & - & - & - & - & 1,20 \\
\hline Buthus egyptiensis & - & - & + & - & - & - & - & 21 \\
\hline Buthus intumescens & - & - & - & - & + & - & - & 1 \\
\hline Buthus Israelis & - & - & - & - & - & + & - & 22,23 \\
\hline Buthus orientalis & + & - & - & - & - & - & - & 1,24 \\
\hline Compsobuthus egyptiensis & - & - & + & + & - & - & - & 1,25 \\
\hline Compsobuthus kabateki & - & - & - & + & - & - & - & 26 \\
\hline Compsobuthus werneri & - & - & - & + & + & + & - & $1,14,27,28$ \\
\hline Compsobuthus longipalpis & - & - & - & - & - & + & - & 29 \\
\hline Egyptobuthus vaissadei & - & + & - & - & - & - & - & 30 \\
\hline Hottentotta minax & - & - & - & + & - & - & - & 11,31 \\
\hline Hottentotta scaber & - & - & - & - & + & - & - & 34 \\
\hline Isometrus maculatus & - & - & - & + & - & - & - & 35 \\
\hline Leiurus quinquestriatus & + & + & + & + & + & + & - & $\begin{array}{l}1,2,3,4,5,6,8 \\
11,12,13,15,32, \\
33\end{array}$ \\
\hline Microbuthus flavorufus & - & - & - & - & + & - & - & 34 \\
\hline Orthochirus aristidis & - & - & - & + & + & - & - & $1,4,6,26,36,37$ \\
\hline Orthochirus innesi & + & - & + & - & + & - & - & $\begin{array}{l}1,5,8,13,37, \\
38,39\end{array}$ \\
\hline Orthochirus scrobiculosus & - & - & - & - & - & + & - & 1,40 \\
\hline Parabuthus hunter & - & - & - & + & - & - & - & 5 \\
\hline Parabuthus leiosoma & - & - & - & - & + & - & - & $1,41,42$ \\
\hline \multicolumn{9}{|l|}{ Euscorpiidae } \\
\hline Euscorpius sicanus & + & - & - & - & - & - & - & 35,43 \\
\hline \multicolumn{9}{|l|}{ Hemiscorpiidae } \\
\hline Hemiscorpius egyptiensis & - & - & - & + & - & - & - & 44 \\
\hline \multicolumn{9}{|l|}{ Scorpionidae } \\
\hline Nebo hierichonticus & - & + & - & + & + & + & - & $\begin{array}{l}1,4,5,8,13,14, \\
15,45\end{array}$ \\
\hline Scorpio maurus & + & - & + & + & + & + & - & $\begin{array}{l}1,4,5,8,13,14, \\
15\end{array}$ \\
\hline Total & 12 & 8 & 8 & 15 & 15 & 9 & 1 & \\
\hline \multicolumn{9}{|l|}{ DUBIOUS SPECIES } \\
\hline \multicolumn{9}{|l|}{ Buthidae } \\
\hline Buthus occitanus & + & - & - & + & + & + & - & $3,5,12,32,35$ \\
\hline Compsobuthus acutecarinatus & + & - & + & + & - & + & - & $5,6,12,18,35$ \\
\hline Hottentotta hottentotta & - & - & - & - & - & - & + & 31 \\
\hline Hottentotta trilineatus & - & - & - & - & - & - & + & 33 \\
\hline
\end{tabular}

$*{ }^{1}$ this study; ${ }^{2}$ Audouin, $1825 ;{ }^{3}$ Pocock, $1895 ;{ }^{4}$ Simon, $1910 ;{ }^{5}$ Gough and Stanley, $1927 ;{ }^{6}$ Birula, 1928; ${ }^{7}$ Roewer, 1943; ${ }^{8}$ Vachon, $1966 ;{ }^{9}$ ElHennawy, 1991; ${ }^{10}$ Hemprich and Ehrenberg, 1829; ${ }^{11}$ Koch, $1875 ;{ }^{12}$ Tullgren, $1909 ;{ }^{13}$ Kinzelbach, 1985; ${ }^{14}$ Levy and Amitai, $1980 ;{ }^{15}$ Moustafa, 1988; ${ }^{16}$ Teruel et al., 2013; ${ }^{17}$ Lourenco, 2006; ${ }^{18}$ Whittick, $1941 ;{ }^{19}$ El-Hennawy, 1991; ${ }^{19} ;{ }^{20}$ Rossi, $2013 ;{ }^{21}$ Lourenço and Cloudsley-Thompson, 2012; ${ }^{22}$ Lourenço et al., 2010; ${ }^{23}$ Yağmur et al., 2011; ${ }^{24}$ Lourenço and Simon, 2012; ${ }^{25}$ Lourenco et al., 2009b; ${ }^{26}$ Kovař́k 2003; ${ }^{27}$ Vachon, 1949 ; ${ }^{28}$ El-Hennawy, 1988; ${ }^{29}$ Levy et al., 1973; ${ }^{30}$ Lourenço, 1999; ${ }^{31}$ Kovař́k, 2007; ${ }^{32}$ Werner, 1902; ${ }^{33}$ Vachon and Stockmann, $1968 ;{ }^{34}$ Lourenco and Duhem, 2007; ${ }^{35}$ Simon 1910; ${ }^{36}$ Vachon and Kinzelbach, 1987; ${ }^{37}$ Lourenco and Leguin 2011; ${ }^{38}$ Boehm 1912; ${ }^{39}$ Vachon, 1952; ${ }^{40}$ ElHennawy, 2003; ${ }^{41}$ Probst, 1973; ${ }^{42}$ El-Hennawy, 2008; ${ }^{43}$ Fet et al., 2003b; ${ }^{44}$ Lourenco, 2011; ${ }^{45}$ Badry, 2013 


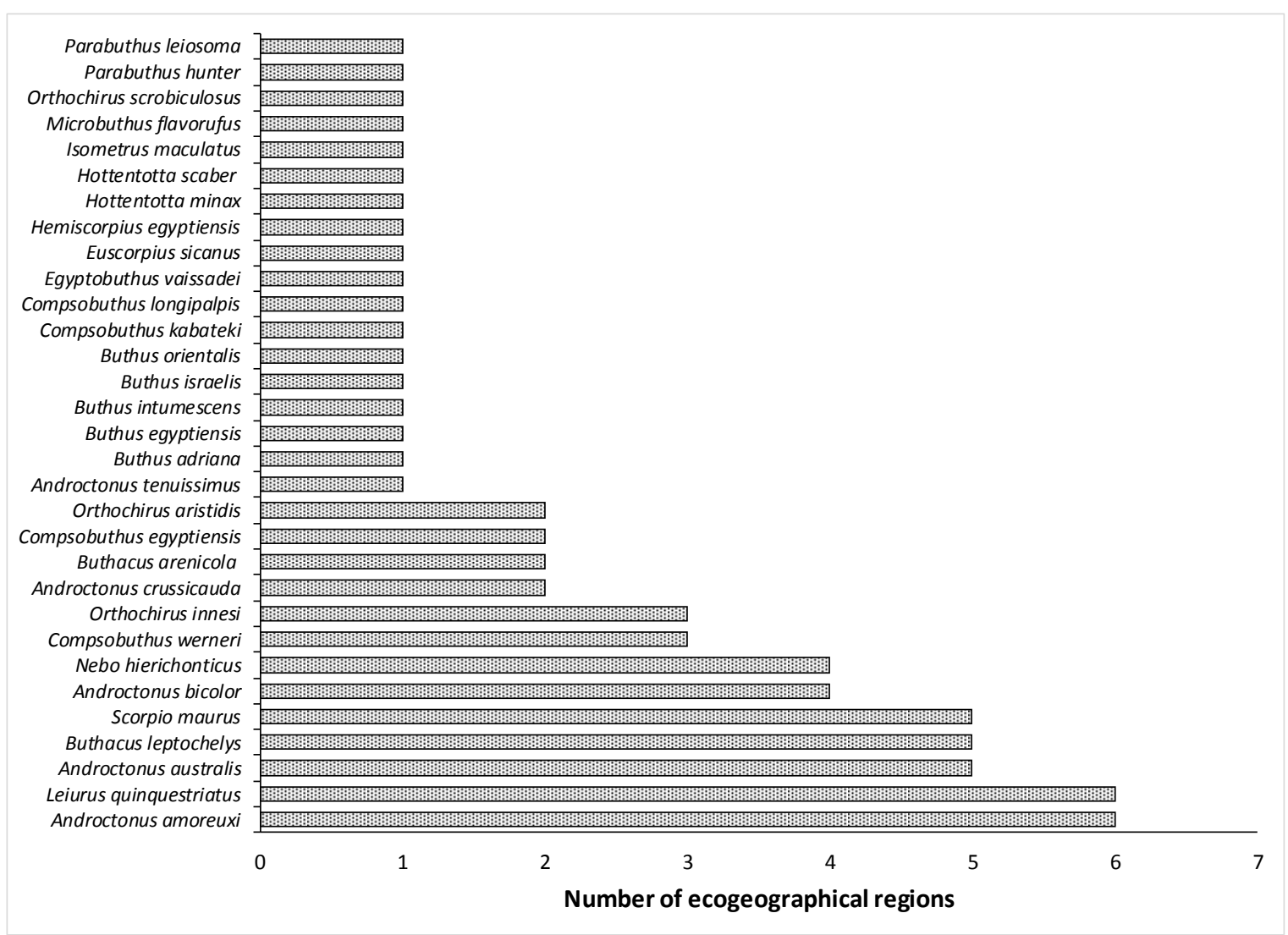

Figure 3. Occurrence of species in available six eco-geographical regions in Egypt.

Corridors, with less severe environmental conditions; penetrate some of the arid and extremely arid regions of northeastern Sahara, linking some of its habitable areas to adjacent, less arid regions. These corridors allow variable levels of faunal exchange between the regions they link. The structure of the present-day scorpion fauna appears to be closely linked to the history of evolution and extinction of these corridors. Two major terrestrial corridors connecting northeastern Sahara to less arid regions may be recognized in Egypt. These are the Nile River and its flood plain, which connect North Africa and the Mediterranean basin to the Afrotropical region, and the climatically mild, Mediterranean coastal belt, which links North Africa to the Levant and the mesic part of the Palearctic region. The Nile Valley, since its connection to the African tropics during the late Pleistocene (Said, 1993), has acted as a major faunal dispersal corridor between the Palearctic Mediterranean basin and the Afrotropical region. In addition, the Nile
Valley seems to have played a pivotal role in structuring the fauna of Egypt in two more ways. First, the Nile and its well-watered flood plain have created an island of non-xeric habitats in the extremely arid desert of the northeastern Sahara. Fauna inhabiting this riverine oasis is typical of mesic habitats and are incapable of penetrating the desert to the east or west of the Nile Valley (Saleh and Basuony, 2014). Second, the Nile Valley cuts across that part of the Sahara creating a typical, knife-like ecological barrier that separates desert-adapted species to the east and the west. The importance of such a formidable zoogeographical barrier is even more evident when one considers how the Nile Delta contributes to the effectiveness of the Isthmus of Suez as a barrier to the flow of fauna between Asia and Africa (Saleh and Basuony, 1998; Saleh et al., 2003).

Palearctic, non-xeric fauna may have also dispersed to North Africa via the narrow 
corridor of the Mediterranean coastal belt, which because of the maritime influence of the Mediterranean has a relatively milder climate than the extremely arid Saharan hinterland. The climate of that belt varies from one place to another, but it becomes particularly arid in Egypt. Species using this coastal route may disperse westwards from the Levant to the Sinai, but are often stopped at the arid Mediterranean coast of Northern Sinai. Species capable of continuing along this route will finally stop at the Isthmus of Suez and Nile Delta with their drastically different environmental conditions. Fauna dispersing eastwards from the more humid areas of the African coast of the Mediterranean is faced with the progressively intensifying aridity in eastern Libya and Egypt, which seem to halt further progress of many species in that direction. For other eastward dispersing species, the Nile Delta will eventually stop further progress.

The present results show that 18 of the 31 species with known collection localities occur in single eco-geographical regions. Furthermore, 12 of these are known from single collection localities (Table, 2) and most are known from a very small number of specimens, in some cases, even a single specimen. Although this may appear to reflect ecological restriction to a particular type of ecogeographical region, it more strongly suggests inadequate distributional data rather than actual ecological restriction. Only six of these seemingly restricted species, were recorded from more than one locality within their apparent restriction eco-geographical region. These are Androctonus tenuissimus, Buthus adrianae and Buthus orientalis, which were collected from far apart WMCD localities, Buthus intumescens and Parabuthus leiosoma which were both collected from EID and Orthochirus scrobiculosus, which was recorded from several localities in South Sinai. The actual geographical distribution of these 12 species with single collection localities remains virtually unknown. On the other hand, seven species (Androctonus amoreuxi, A. australis, A. bicolor, Buthacus leptochelys, Leiurus quinquestraiatus, Nebo hierichonticus and Scorpio maurus) are widespread throughout the country occurring in four or more of the six eco-geographical regions and appear to be habitat generalists (Mirshamsi, 2011). Most of these species have wide general distribution across North Africa and the Middle East.

The dendrogram in Figure 4 shows the results of cluster analysis of the scorpion faunal composition of different eco-geographical regions in Egypt. The dendrogram shows two main clusters. One consisting of the scorpion fauna west of the Nile (WMCD and WID) in addition to that of the Mediterranean coastal deserts of the Sinai Peninsula SMCD). The other cluster encompasses the scorpion fauna of the Nile Valley and Delta and regions to the east of it (EID and SID). In the first cluster, the dendrogram shows the clustering of the SMCD and WID together and away from the WMCD. The scorpion fauna of these two predominantly hyper-arid regions is mostly made of widely distributed species with wide ecological tolerance, in addition to those that are particularly adapted to extreme desert conditions. For the WID, five of the eight recorded species are widespread in Egypt, occurring in at least five of the six surveyed eco-geographical regions (Table 2). The same widespread species, except Scorpio maurus also occur in the SMCD. Two of the three WID species (Buthus egyptiensis, and Compsobuthus egyptieness) are only known from the oases of that desert. The two species were only known from their type locality in Siwa Oasis (Lourenço et al., 2009b; Lourenço \& Cloudsley-Thompson, 2012) but our collection expanded the known range of Compsobuthus egyptieness to cover all oases of the Egyptian Western Desert, including the riverine oasis of Faiyum which is linked to the Nile Valley via a branch of the Nile River. The third species Orthochirus innesi, is somewhat widespread occurring in addition to the WID, in the WMCD and EID east of the Nile River. The know range of that species extends west into 
Libya, Algeria and Tunisia (Lourenço \& Leguin, 2011).

The disjunct pattern of distribution of the WID habitats and its scorpion fauna suggest that the present-day isolated populations of different scorpion species represents relicts of a wider distribution during the early Holocene when aridity was less intense in North Africa (Roberts, 1998). When the present day hyperarid conditions were reached around midHolocene, populations of these species were isolated in patches of suitable, mostly groundwater-based habitats that now characterize that extremely arid desert.

Similar to the SMCD, the WID scorpion fauna consists mostly of widespread species (Table 2). Two species also occur in SID (Androctonus crussicauda, and Nebo hierichonticus) and one (Egyptobuthus vaissadei) is only known from its SMCD type locality (Lourenço, 1999), mostly groundwaterbased habitats that now characterize that extremely arid desert. The WMCD scorpion fauna consists of 12 species and includes six of the seven widespread species (Table 2). Two predominantly North African species; Orthochirus innesi and Buthus adrianae occur in WMCD with ranges extending into the inland desert both east of the Nile River for the former, and the EID and the Sinai Peninsula for the latter. Four species (Androctonus crussicauda, Buthus adrianae, Buthus orientalis and Euscorpius sicanus) are only known in Egypt from this eco-geographical region. Androctonus crussicauda is only known from its WMCD type localities while the other three are known from other areas outside Egypt.

The second main cluster of the dendrogram (Figure 4), shows the close clustering of NVD and regions to the east (EID and SID). Although the Gulf of Suez now separates Southern Sinai from the Eastern Desert, this separation was not always present. During drier periods of the Pleistocene, the Gulf of Suez had a much-reduced area and the Sinai Peninsula and the Eastern Desert formed one, largely continuous arid mountain zone (Por, 1971; Derricourt, 2005). The connection allowed uninterrupted faunal exchange between the now separated regions. Furthermore, the ecological settings of the two regions continued to be generally similar. Habitats of these two predominantly hilly regions are essentially restricted to the drainage lines. Wadis draining large watersheds in these arid or even hyperarid regions support much more luxuriant vegetation cover than the surrounding areas and often support relatively diverse animal communities (Saleh, 1993). Many of the wadis drain into the Nile and support a continuum between the xeric habitats and biota of desert wadis and the well-watered Nile Valley riverine oasis.

The largest number of species are recorded from the Eastern Desert (Table 2). Of the 15 species recorded from that region, seven are widespread species occurring in at least 4 of the six eco-geographical regions, and have a relatively wide distribution in North Africa and the Middle East. Four species (Buthus intumescens, Hottentotta scaber, Microbuthus flavorufus, and Parabuthus leiosoma) are only restricted to that region and the remaining four species occur in some of the other ecogeographical regions of Egypt. The Nile Valley and Delta have 15 species, seven of which are widespread species and five are known in Egypt only from that eco-geographical region (Compsobuthus kabateki, Hottentotta minax, Isometrus maculatus, Parabuthus hunteri, and Hemiscorpius egyptiensis). Both Compsobuthus kabateki and Hemiscorpius egyptiensis are only known from their type localities in upper Nile Valley of Egypt (Kovařík, 2003a; Lourenço, 2011). Hottentotta minax is only from the Cairo area, most likely in the Nile Valley and is widespread into sub-Saharan Africa. Also, Isometrus maculatus is only known from its collection locality referred to as Port Said and Alexandria (Simon, 1910). In addition, Parabuthus hunteri is only known from the Nile Valley of Egypt and Sudan (Kaltsas et al., 2008). 
SID has nine species, including four widespread species. Three species (Buthus israelis, Compsobuthus longipalpis and Orthochirus scrobiculosus) are known in Egypt only from this ecoregion and relatively small area in the deserts of Jordan and Palestine. Compsobuthus werneri is a widespread species in Africa and southwestern Asia is only known in Egypt from SID, EID and NVD. Androctonus crussicauda occurs only in southern and northern Sinai and Egypt, but has a wider range in Asia (Kaltsas et al., 2008). Other than the widespread species that seem to form a grou of habitat generalists (Mirshamsi, 2011), the scorpoin fauna of the Nile Valley and Delta includes only one species that also inhabits the inland Western Desert (Compsobuthus egyptiensis) and two that also occur in the Eastern Desert (Compsobuthus werneri and Orthochirus aristidis).

The above analysis shows that the distribution and composition of scorpion fauna of Egypt is dictated by ecological history of the region as well as by present-day habitat features. Major, but relatively recent land form features that now separate some ecogeographical regions appear to have limited influence on the present-day faunal composition and distribution patterns. The Nile Delta, for instance, is a relatively recent geomorphologic feature that interrupts the Levant - North Africa Mediterranean maritime exchange corridor for animals adapted to mild desert conditions since Late Pleistocene (Said, 1993). Yet fauna of the Mediterranean costal belt east and west of the Nile Delta show some notable similarity that reflects the long, PlioPleistocene connection that predates the formation of the present-day Nile Delta (Said, 1990; 1993). Similarly, scorpion faunas of wadis in hilly areas east and west of the Gulf of Suez (SID and EID), are remarkably close. This may also reflect the frequent connection between the two regions during successive periods when the Gulf of Suez was fragmented or even disappeared altogether (Said, 1990; Derricourt, 2005;). The Nile River and its densely vegetated flood plain seem to also separate faunas of inland habitats into that of the highly disjunct populations of the hyperarid, inland Western Desert, and that of the wadis, which enjoy locally less arid habitats in the Eastern Desert and the Southern Sinai.

\section{REFERENCES}

Abu Al-Izz, M. S. (1971). Landforms of Egypt. Cairo: The American University in Cairo Press. Dar Al Maaref.

Anderson, R. C. (1983). Scorpions: The ancient arachnids. Idaho Museum of Natural History. Special Publ., 8, 1-21.

Audouin, J. V. (1825). Explication sommaire des planches de polypes de l'Égypte et de la Syrie, publiées par Jules-César Savigny.". In T. Premier (Ed.), Description de l'Égypte, ou Recueil des observations et des recherches qui ont été faites en Égypte pendant l'expédition de l'armée française. 1809 (pp. 172-178). Paris: Histoire Naturelle.

Badry, A. (2013). Studies on some scorpion species from Gabal Elba protected area, Red Sea, Egypt. M.Sc.Thesis, Zoology Dep., Al Azhar University, Assiut, Egypt.

Badry, A., Younes M., Sarhan M. and Saleh M. (2017). On the scorpion fauna of Egypt, with an identification key (Arachnida: Scorpiones). Zoology in the Middle East, 63: $1-13$.

Basuony, M. I., and Saleh, M. (2005). The Zoril, Ictonyx striatus erythreae De Winton, 1898 in Egypt. Egyptian Journal of Biology, 7, 103-107.

Béatrix, M. (2001). Préhistoire l'Égypte, Des Premiers Hommes Aux Premiers Pharaons (Armand Col). Cairo: Arabic translation by Mahir Gowigaty, Dar El Fikr. pp. 77.

Birula, A. A. B. (1928). Vissenschaftliche Ergebnisse der mit Unterstiatzung der Akademie der Wissenschaften in Wien aus der Erbschaft treitl von F.Werner . unternommenen Zoologischen Exped nach dem Anglo-Agyptischen Sudan (Kordofan) 1914. XXV.Skorpione. Skorpione. Denschr. Wiss. Wein, 101, 79-88.

Boehm, R. (1912). Note sur Orthochirus innesi E. Simon (Scorpions). Bull.Soc.ent.Egypte, 3, 27.

Derricourt, R. (2005). Getting "Out of Africa": Sea crossings, land crossings and culture in the Hominin migrations. Journal of World 
Prehistory, 19(2), 119-132.

Dobson, M., and Wright, A. (2000). Faunal relationships and zoogeographical affinities of mammals in north-west Africa. Journal of Biogeography, 27(2), 417-424.

El-Hennawy, H. K. (1987). A simplified key to Egyptian scorpion species (Arachnida: Scorpionida). Serket, 1(1), 15-17.

El-Hennawy, H. K. (1988). A new record of Compsobuthus werneri (Birula) 1908 (Scorpienida: Buthidae) from Egypt. Serket, 1(2), 21.

El-Hennawy, H. K. (1991). Arachnida of Wadi ElRaiyan (Egypt). Serket, 2(3), 81-90.

El-Hennawy, H. K. (1992). A catalogue of the scorpions described from the Arab countries (1758-1990) (Arachnida: Scorpionida). Serket, 2(4), 95-123.

El-Hennawy, H. K. (2003). Arachnids in three Egyptian coastal protected areas on Aqaba gulf (Red Sea). Serket, 8(4), 151-163.

El-Hennawy, H. K. (2014). Updated List of Scorpions of Egypt. Serket, 1-4.

Fet, V., Gantenbein, B., Soleglad, M. E., Vignoli, V., Salomone, N., Fet, E. V., and Schembri, P. J. (2003). New molecular and morphological data on the "Euscorpius carpathicus" species complex (Scorpiones: Euscorpiidae) from Italy, Malta, and Greece justify the elevation of E. c. sicanus (C. L. Koch, 1837) to the species level. Revue Suisse de Zoologie, 110(2), 355-379.

Gough, L. H., and Stanley, H. (1927). Key to identification of the Egyptian scorpions. Bulletin of Ministry of Agriculture, Egypt, 76, 1-7.

Hemprich, E. G., and Ehrenberg, C. G. (1829). Vorlaufige Uebersicht der in Nord-Afrika und West-Asien einheimischen Scorpione und deren geographischen Verbreitung. Gesells. Nat. Freunde Verh., I, 348-362.

Kaltsas, D., Stathi, I., and Fet, V. (2008). Scorpion of the Eastern Miditerranean. Advances in Arachnology and Developmental Biology, 12, 209-246.

Kassas, M. (1993). Habitat diversity: Egypt. NBU Publication (1).

Kinzelbach, R. (1985). Vorderer Orient. Scorpione (Arachnida: Scorpiones). Tübinger Atlas Der Vor- Derer Orients (TAV),Karte Nr. A VI 14.2.
Koch, C. L. (1875). Agyptische und Abyssenische Arachniden gesmmelt von Herrn C. Jickelli. Nurnberg.

Kovařík, F. (2003). Eight new species of Compsobuthus Vachon , 1949 from Africa and Asia ( Scorpiones: Buthidae). Serket, 8(3), 87-112.

Kovařík, F. (2007). A revision of the genus Hottentotta Birula, 1908, with descriptions of four new species". Euscorpius, 58, 1-105.

Lamoral, B. H. (1980). A reappraisal of suprageneric classification of Recent scorpions and their zoogeography. In Verhandlungen. 8th Internationaler Arachnologen-Kongress abgehalten an der Universität für Bodenkultur Wien (pp. 439444). Egermann, Vienna.

Levy, G., and Amitai, P. (1980). Fauna Palaestina. Arachnida I: Scorpiones. Israel Academy of Sciences and Humanities, Jerusalem.

Levy, G., Amitai, P. and Shulov, A. (1973). New scorpions from Israel, Jordan and Arabia. Zoological Journal of the Linnean Society, 52(2), 113-140.

Lourenço, W. R. (1999). New genus and new species of scorpion from Egypt, belonging to the family Buthidae Simon. Revue Suisse de Zoologie, 106(3), 591-598.

Lourenço, W. R. (2006). Further considerations on the genus Buthacus Birula, 1908 (Scorpiones, Buthidae), with a description of one new and two new subspecies. Boletín Sociedad Entomológica Aragonesa, 38(2), 59-70.

Lourenço, W. R. (2011). More about the African speciesof Hemiscorpius Peters, 1861 from Egypt. Boletín de La Sociedad Entomológica Aragonesa, 49, 23-26.

Lourenço, W. R., and Cloudsley-Thompson, J. L. (2012). A new species of Buthus Leach, 1815 from Egypt (Scorpiones, Buthidae). Entomologische Mitteilungen Aus Dem Zoologischen Museum Hamburg, 16(187), 11-18.

Lourenço, W. R., and Duhem, B. (2007). Observations on the remarkable disrupted geographical distribution of the genus Microbuthus Kraepelin, 1898 in North Africa, with the description of a new species from Egypt (Scorpiones, Buthidae). Comptes Rendus Biologies, 330(5), 439-45.

Lourenço, W. R., and Leguin, E. E. (2011). Further Considerations on the species of the genus Orthochirus Karsch, 1891 from Africa, with 
description of three new species (Scorpiones: Buthidae). Euscorpius, 1861(123), 1-19.

Lourenço, W. R. and Simon, E. (2012). Confirmation of a new species of Buthus Leach, 1815 from Alex- andria, Egypt (Scorpiones, Buthidae). Serket, 13((1/2)), 815.

Lourenço, W. R., Sun, D., and Zhu, M. S. (2009 a). About the presence of the genus Buthus Leach, 1815 in Mauritania, with description of a new species (Scorpiones, Buthidae). Boletín de La Sociedad Entomol\{ó\}gica Aragonesa Socie, 44(179), 71-75.

Lourenço, W. R., Sun, D., and Zhu, M. (2009 b). A bout some Compsobuthus Vachon, 1949 from Africa and the Middle East with the description of a new species (scorpiones, buthidae). Boletín Sociedad Entomológica Aragonesa, 45, 5-10.

Lourenço, W. R., Ya, E. A., and Duhem, B. (2010). A new species of Buthus Leach , 1815 from Jordan. Zoology in the Middle East, 49(1), 95-99.

Mirshamsi, O. (2011). History of study and checklist of the scorpion fauna (Arachnida: Scorpiones) of Iran. Progress in Biological Sciences, 1(2), 16-28.

Morrone, J. J., and Crisci, J. V. (1995). Historical biogeography: introduction to methods. Ann. Rev. Ecol. Syst., 26, 373-401.

Moustafa, A. A. (1988). Studies on scorpions in ST. Catherine and Wadi Feiran Regions, South Sinai. M.Sc. Thesis, Faculty of Science, Suez Canal Univ. Egypt.

Nelson, G., and Platnick, N. (1980). A vicariance approach to historical biogeography. Biosc., 30, 339-43.

Pallary, P. (1937). Notes sur divers scorpions de l'Afrique du Nord. Arch. Inst. Pasteur Algérie, 15(1), 97-101.

Pocock, R. I. I. (1895). On the Arachnida and Myriopoda obtained by Dr. Anderson's Collector during Mr. T. Bent's Expedition to the Hadramaut, South Arabia; with a Supplement upon the Scorpions obtained by Dr. Anderson in Egypt and the Eastern Soudan. Journal of the Linnean Society of London, Zoology, 25(161), 292-316.

Por, F. D. (1971). One hundred years of Suez Canal - A century of Lessepsian migration: retrospect and viewpoints. Systematic Zoology, 20(2), 138-159.
Probst, P. J. (1973). A review of the scorpions of East Africa with special regard to Kenya and Tanzania. Acta Tropica, 30(4), 312-35.

Roberts, N. (1998). The Holocene: An environmental history. 108 Cowley Road, Oxford, UK: Blackwell Publisher Ltd.

Roewer, C. F. (1943). Uber eine neuerworbene Sammlung von Skorpionen des NaturMuseums Senckenberg.". Senckenbergiana, 26(4), 205-244.

Rossi, A. (2013). A new species of the genus Buthus Leach, 1815 from Egypt (Scorpion: Buthidae). Riv. Mus. Civ. Sc. Nat. "E. Caffi" Bergamo, 26, 187-194.

Said, R. (1990). The Geology of Egypt. Rotterdam: Balkema Publishers.

Said, R. (1993). The Nile River (in Arabic). Cairo: Dar El Helal.

Saleh, M. A. (1993). Habitat diversity and land vertebrates. In Habitat Diversity of Egypt, Kassas, M. ed. Pub. Nat. Biodiver. Unit, (1), 67-131. ISO 690.

Saleh, M. A. (1997). Amphibians and Reptiles of Egypt. [Cairo]: Egyptian Environmental Affairs Agency. (Publication of National Biodiversity Unit (Egypt) 6.

Saleh, M. A. and Basuony, M. I. (1998). A contribution to the mammalogy of the Sinai Peninsula. Mammal., 62(4), 121-139.

Saleh, M. A. and Basuony, M. I. (2014). Mammals of the Genus Canis Linnaeus, 1758 (Canidae , Carnivora) in Egypt. Egypt. J. Zool., 62, 4992.

Saleh, M. A., Basuony, M. I. and Tolba, M. (2003). Biodiversity and Zoogeography of the Qattara Depression, Western Desert, Egypt. Egypt. J. Zool., 40, 357-387.

Shata, A. (1959). Structural development of the Sinai Peninsula (Egypt). In Proc. 20th Int. Geol. Congr., , Mexico,1956 (pp. 225-249).

Simon, E. (1910). Révision des scorpions d'egypte. Bulletin de La Société Entomologique Degypte, 1910, 57-87.

Sissom, W. D. (1990). Systematics, biogeography and paleontology. In Polis, G. A. (ed.), The Biology of the scorpions, pp. 64-160. Stanford University Press, Palo Alto, CA.

Stahnke, H. L. (1972). UV light, a useful field tool. BioScience, 22(10), 604-607.

Teruel, R., Kovařík, F., and Turiel, C. (2013). A new species of Androctonus Ehrenberg, 1828 
from northwestern Egypt (Scorpiones: Buthidae). Euscorpius, 177(177), 1-12.

Tullgren, A. (1909). Solifugae, Scorpiones und Chelonethi aus Agypten und dem Sudan. In L. A. Jägerskiöld (Ed.), Results of the Swedish Zoological Expedition to Egypt, 1901, 3(21), A: 1-12. [Uppsala]: Library of the Royal University of Uppsala.

Vachon, M. (1949). Études sur les Scorpions (suite). Chapitre III (suite). Déscription des scorpions du Nord de l'Afrique. Archives de l'Institut Pasteur d'Algérie, 27(1), 242-292.

Vachon, M. (1952). Etudes sur les scorpions. Alger: Institut Pasteur d'Algérie.

Vachon, M. (1966). Liste des scorpions connus en Egypt, Arabie, Israel, Liban, Syrie, Jordanie, Turquie, Irak, Iran. Toxicon, 4, 209-218.

Vachon, M., and Kinzelbach, R. (1987). On the taxonomy and distribution of the scorpions of the Middle East. In: F. Krupp, W. Schneider, and R. Kinzelbach (Eds.), Proceedings of the Symposium on the Fauna and Zoogeography of the Middle East (pp. 91-103). Mainz.

Vachon, M., and Stockmann, R. (1968). Contribution á l'étude des scorpions africains appartenant au genre Buthotus Vachon 1949 et étude de la variabilité. Monitore Zoologico Italiano, 2(1), 81-149.

Werner, F. (1902). Die Scorpione, Pedipalpen und Solifugen in der zoologisch-vergleichendanatomischen Sammlung der Universität Wien. Scorpiones. Verhandlungen Der Kaiserlich-Königlichen ZoologishBotanischen Gesellschaft in Wien, 52, 595608.

Whittick, R. J. (1941). Arachnida: Scorpiones, Pedipalpi and Solifugae. Expedition to SouthWest Arabia, 1937-38. Br.Mus.Nat.Hist.London, 1(5), 43-49.

Williams, S. S. C. (1968). Scorpion preservation for taxonomic and morphological studies. The Wasmann Journal of Biology, 26(1), 133136.

Yağmur, E. A., Koç, H., and Lourenço, W. R. (2011). A new species of Buthus Leach, 1815 from Cyprus (Scorpiones, Buthidae). ZooKeys, 115, 27-28. 
